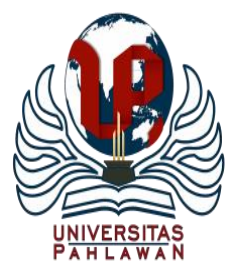

Jurnal Abdidas Volume 2 Nomor 3 Tahun 2021 Halaman 603-610

JURNAL ABDIDAS

http://abdidas.org/index.php/abdidas

\title{
Bahaya Pornografi Melalui Media Elektronik bagi Remaja Berbasis Penyuluhan Hukum
}

\author{
Suci Flambonita ${ }^{1}$, Vera Novianti ${ }^{2}$, Artha Febriansyah ${ }^{3}$ \\ Ilmu Hukum, Fakultas Hukum, Universitas Sriwijaya, Indonesia ${ }^{1,2,3}$ \\ E-mail : suciflambonita@fh.unsri.acid ${ }^{1}$, veranoviantiamri@gmail.com ${ }^{2}$, arthafebrian@unsri.ac.id ${ }^{3}$
}

\begin{abstract}
Abstrak
Penyuluhan tentang bahaya pornografi melalui media elektronik bagi remaja sebagai akibat dari kemajuan komunikasi/teknologi tersebut, justru sangat mengganggu psikologis perkembangan jiwa anak-anak dan remaja. Hal ini dikarenakan melihat dan menonton gambar dan film yang bukan konsumsi mereka, mereka meniru adegan yang ada di dalam internet tersebut. Bertalian dengan hal pornografi, ada semacam dampak yang sangat signifikan yaitu jika sudah maniak terhadap tontotan yang berbau pornografi, maka akan menjadi kecanduan yang disebut kecanduan pornografi. Dimana perilaku berulang untuk melihat hal-hal yang merangsang nafsu seksual, dapat merusak kesehatan otak dan kehidupan seseorang, serta pecandu pornografi tidak sanggup menghentikannya. Pemanfaatan teknologi khususnya di bidang visualisasi melalui media elektronik menjadikan manusia lebih maju cara berpikirnya. Manusia dapat mengenal orang lain di belahan dunia manapun melalui jaringan nasional maupun internasional, secara bilateral maupun multilateral yang diakses melalui situs dalam internet. Manusia bisa mengenal manusia lain melalui jalur internet melalui Facebook, Twitter, Instagram, Vine, Line, WhatsApp, Bee Talk, Skype, dan masih banyak aplikasi yang lain. Dari semua fasilitas tersebut, secara keseluruhan dapat digunakan secara online. Internet sebagai salah satu indikator mempermudah segala gerak diberbagai lini kehidupan dan memudahkan untuk mengakses data apapun, termasuk gambar-gambar/film yang dikategorikan sebagai tontonan orang dewasa atau 17 tahun ke atas. Untuk itu, diperlukan penyuluhan hukum sebagai upaya preventif dalam mencegah bahaya pornografi pada kalangan remaja khususnya. Metode yang digunakan ceramah, diskusi dan tanya jawab. Hasil dari penyuluhan tersebut adalah siswa memahami yang dimaksud dengan pornografi, jenis-jenis serta bahaya pornografi, sehingga bahaya pornografi melalui media elektronik bagi remaja sebagai akibat dari kemajuan komunikasi/teknologi tersebut dapat diminimalisir.
\end{abstract}

Kata kunci: pornografi, media elektronik, remaja

\begin{abstract}
Counseling about the dangers of pornography through electronic media for teenagers as a result of advances in communication/ technology is actually very disturbing psychological development of the soul of children and adolescents due to seeing and watching pictures and films that are not their consumption even until they imitate the scenes on the internet. In connection with pornography, there is a very significant impact, namely if you are a maniac for pornographic spectacles, you will become an addiction called pornography addiction, where repeated behavior to see things that stimulate sexual desire can damage one's brain health and life, and porn addicts can't stop it. Utilization of technology, especially in the field of visualization through electronic media, makes humans more advanced in their way of thinking, where humans can get to know other people in any part of the world through bilateral and multilateral national and international networks that are accessed through sites on the internet, humans can get to know other humans through the internet via Facebook, Twitter, Instagram, Vine, Line, WhatsApp, Bee Talk, Skype, and many other applications from all of these facilities as a whole can be used online. The internet as one of the indicators makes it easier for all movements in various lines of life and makes it easier to access any data, including pictures/films that are categorized as adult viewing or 17 years and over, for that legal counseling is needed as a preventive effort to prevent the dangers of pornography among people. teenagers in particular. The method used is lecture, discussion and question and answer. The results of the counseling that students understand what is meant by pornography, the types and dangers of pornography so that the dangers of pornography through electronic media for teenagers as a result of these communication/technology advances can be minimized.
\end{abstract}

Keywords: pornograph, electronic, adult

Copyright (c) 2021 Suci Flambonita, Vera Novianti, Artha Febriansyah

$\triangle$ Corresponding author

Address : Jalan Silaberanti Lr. Cempaka

Email : suciflambonita@fh.unsri.ac.id

ISSN 2721- 9224 (Media Cetak)

DOI : https://doi.org/10.31004/abdidas.v2i3.324

ISSN 2721- 9216 (Media Online) 
604 Bahaya Pornografi Melalui Media Elektronik Bagi Remaja Berbasis Penyuluhan Hukum-Suci Flambonita, Vera Novianti, Artha Febriansyah

DOI: https://doi.org/10.31004/abdidas.v2i3.324

\section{PENDAHULUAN}

Pada zaman sekarang, era modernisasi, seiring perkembang zaman orang lebih mengenal teknologi yang sudah lebih canggih dari sebelumnya. Misalnya, laptop dengan berbagai tipe dan merk yang bermacam multifungsi dengan generasi teknologi dari komputer yang komponennya lebih canggih. Bila ditelaah lebih dalam, bahwasannya fungsi teknologi bila dilihat dari sudut pandang yang positif, maka akan banyak sekali kegunaan atau fungsi dari teknologi modern itu sendiri dan sangat membantu manusia dalam menjalankan aktivitas. Sedangkan jika dilihat dari sisi negatif, teknologi menjadikan manusia "ketergantungan" akan teknologi tersebut. Contohnya mesin cuci untuk mencuci pakaian dan masih banyak lain hasil teknologi, menjadikan semuanya bisa dapat diselesaikan dengan cepat dan tepat pada waktu. Dampak negatif juga dapat muncul dalam penggunaan teknologi jika dilakukan dengan cara yang salah atau digunakan tidak sebagaimana mestinya.

Kemajuan teknologi ibarat dua mata pisau, di satu sisi sangat menguntungkan, di sisi lain bisa berbahaya. Salah satu dampak negatif dari kemajuan teknologi adalah merebaknya pornografi. Di era teknologi seperti saat ini, pornografi sangat mudah diakses melalui media, terutama media maya. Harga rental internet yang terjangkau oleh remaja dan anak-anak, hingga media telepon seluler yang mempunyai aplikasi internet, membuat pornografi semakin mudah diakses melalui media maya. Tidak hanya itu, tidak sedikit buku, majalah, film dan komik yang secara sengaja maupun tidak, memuat unsur pornografi untuk meningkatkan nilai jualnya (Ali \& E, 2018). Dengan adanya gadget yang selalu dibawa memungkinkan para siswa bisa selalu mengakses film porno (Hariyani et al., 2012).

Perkembangan teknologi yang sangat canggih dan tidak terbendung lagi dimanfaatkan segelintir orang untuk berbuat curang, misalnya para brooker atau hacker yang memanfaatkan keahlian mereka dengan memasukan akses untuk merusak suatu sistem pertahanan tertentu.

Pemanfaatan teknologi khususnya di bidang visualisasi melalui media elektronik menjadikan manusia lebih maju dalam cara. Dimana manusia dapat mengenal orang lain di belahan dunia manapun melalui jaringan nasional maupun internasional, secara bilateral maupun multilateral yang diakses melalui situs dalam internet, manusia bisa mengenal manusia lain melalui jalur internet melalui Facebook, Twitter, Instagram, Vine, Line, WhatsApp, Bee Talk, Skype, dan masih banyak aplikasi yang lain. Semua fasilitas tersebut secara keseluruhan dapat digunakan secara online. Internet sebagai salah satu indikator mempermudah segala gerak diberbagai lini kehidupan dan memudahkan untuk mengakses data apapun, termasuk gambar-gambar/ film yang dikategorikan sebagai tontonan orang dewasa atau 17 tahun ke atas. Efek visualisasi yang berupa gambar-gambar ataupun animasi dan film tersebut dapat diakses dengan mudah, sehingga menjadikan internet tidak hanya digunakan kalangan dewasa tetapi juga anak-anak. Dengan hanya bantuan bluetooth melalui perangkat handphone yang dapat mengakses internet, memudahkan anak-anak dan remaja dapat mengakses dengan mudah gambar 
605 Bahaya Pornografi Melalui Media Elektronik Bagi Remaja Berbasis Penyuluhan Hukum-Suci Flambonita, Vera Novianti, Artha Febriansyah

DOI: https://doi.org/10.31004/abdidas.v2i3.324

atau film-film yang termasuk kategori tontonan orang dewasa atau kategori 17 tahun ke atas.

Menjadi satu keprihatinan tersendiri bahwasannya Indonesia menduduki peringkat ketiga sebagai negara dengan jumlah pengakses pornografi terbanyak. Karenanya sangat diperlukan suatu penangkal secara khusus, agar remaja-remaja di Indonesia tidak secara leluasa dapat mengakses konten yang berbau pornografi. Seperti yang diketahui pornografi memberikan banyak dampak negatif bagi remaja. Seperti banyaknya remaja yang melakukan perilaku menyimpang, meningkatnya jumlah remaja yang berperilaku seksual aktif, juga akan meningkatkan kasus Kehamilan Tidak Diinginkan (KTD), tindakan aborsi, dan kerusakan otak (Marchira, 2019).

Teknologi tidak dapat dipisahkan dari pembangunan manusia. Remaja telah beradaptasi dengan relatif mudah terhadap teknologi informasi perilaku pornografi pada remaja laki-laki dan perempuan yang didorong oleh beberapa faktor. Salah satunya adalah penggunaan internet melalui handphone (Rina \& Tianingrum, 2019).

Akibat dari kemajuan komunikasi/teknologi tersebut justru sangat mengganggu psikologis perkembangan jiwa anak-anak dan remaja. Dikarenakan melihat dan menonton gambar dan film yang bukan konsumsi mereka, mereka meniru adegan yang ada di dalam internet tersebut, sampai ada adegan yang dilakukan oleh siswa sebuah SMP di daerah Bangka yang aksesnya dapat ditemukan di YouTube (Suyatno, 2011). Bertalian dengan hal pornografi, ada semacam dampak yang sangat signifikan yaitu jika sudah maniak terhadap tontotan yang berbau pornografi, maka akan menjadi kecanduan yang disebut kecanduan pornografi. Perilaku berulang untuk melihat halhal yang merangsang nafsu seksual, dapat merusak kesehatan otak dan kehidupan seseorang, serta pecandu pornografi tidak sanggup menghentikannya. Ahli bidang kecanduan pornografi, pornografi dapat menyebabkan kerusakan pada lima bagian otak, terutama pada pre frontal corteks (bagian otak yang tepat berada di belakang dahi). Berbanding dengan kecanduan narkoba menyebabkan kerusakan pada tiga bagian otak (Haidar \& Apsari, 2020). Ciri-ciri orang yang sudah kecanduan pornografi, sebagai berikut:

1. Suka menyendiri,

2. Bicara tidak melihat mata lawan bicara,

3. Prestasi di sekolah menurun,

4. Suka berbicara jorok/buruk,

5. Berperilaku yg tidak patut,

6. Suka berkhayal tentang pornografi,

7. Banyak minum dan banyak pipis,

8. Suka menonton, bila dihentikan akan mengamuk (tantrum).

Dampak yang paling nyata adalah nilai pelajaran siswa di sekolah akan mengalami penurunan secara drastis. Oleh sebab itu, banyaknya situs porno maupun akses mudah untuk memperoleh gambar porno melalui media elektronik, sangat berbahaya sekali bagi perkembangan jiwa anak, khususnya anak-anak usia sekolah. Karena pada prinsipnya anak adalah sebagai cikal bakal generasi penerus. 


\section{METODE}

Kegiatan ini bertujuan untuk memberikan informasi dan pengetahuan tentang penyuluhan tentang bahaya pornografi melalui media elektronik bagi remaja.

\section{Khalayak Sasaran Strategis}

Khalayak strategis dari kegiatan ini adalah remaja, khususnya pelajar Sekolah Menengah Atas di daerah Bangka yang berjumlah \pm 30 orang, terdiri laki-laki dan perempuan, terdiri dari kelas 10 sampai dengan kelas 12, dimana diwakili oleh setiap kelas. Diharapkan setelah diadakan kegiatan ini, dapat menyebarluaskan informasi yang diperoleh dari Tim Penyuluh Fakultas Hukum UNSRI kepada teman-teman dan lingkungan bermain, bahkan keluarga terkait bahaya pornografi yang memang sedang mengancam khususnya bagi remaja.

\section{Waktu Pelaksanaan}

Penyuluhan hukum tentang bahaya pornografi melalui media elektronik bagi remaja di SMA 2 Pangkal Pinang Provinsi Kepulauan Bangka Belitung dilaksanakan pada Medio November 2020.

\section{Metode Kegiatan}

Dengan melihat sifat dari kegiatan dari penyuluhan hukum ini, maka penyuluhan dilaksanakan dengan metode/ cara sebagai berikut:

a. Ceramah

Metode yang dipakai adalah penyuluhan atau ceramah kepada peserta atau para pelajar SMA N 2 Kepuluan Bangka dengan cara tatap muka langsung. Tim penyuluh menyampaikan materi yang telah disusun dengan menggunakan slide PowerPoint. Sebagai wacana memberikan informasi tentang bahaya pornogafi melalui media elektronik bagi remaja, diharapkan adanya luaran atau output kedepannya agar remaja khususnya pelajar setempat dapat mengetahui bagaimana bahaya dari pornografi tersebut. Kemudian diberikan kesempatan yang seluas-luasnya kepada peserta untuk berdiskusi dan menyampaikan pendapatnya tentang materi yang disampaikan oleh tim penyuluh.

b. Diskusi

Mengadakan tanya jawab antara tim penyuluh dengan peserta, sehingga mencapai satu pemahaman tentang apa yang menjadi bahaya dari pornografi melalui media elektronik bagi remaja tersebut.

Metode ini digunakan untuk memberikan pemahaman yang lengkap kepada siswa SMAN 2 Pangkal Pinang, Provinsi Kepulauan Bangka Belitung sebagai peserta penyuluhan tentang bahaya pornografi dan akibatnya. Dalam ceramah diuraikan kerangka materi secara lengkap, jelas mudah dipahami dan aplikatif. Metode ceramah dalam kegiatan ini diusahakan untuk tidak berteori secara berlarut-larut, melainkan menekankan pada contoh dan permasalahan yang dihadapi peserta penyuluhan. Kedua diskusi berupa tanya jawab dua arah antara siswa dan tim penyuluh, sebagai salah satu cara yang dipilih untuk lebih memberi kesempatan kepada para siswa sebagai peserta penyuluhan untuk memahami materi tentang bahaya dan akibat dari pornografi serta pengaturannya di Indonesia. Para peserta juga diberikan kesempatan untuk memberikan masukan, bertanya dan memberikan sanggahan 
607 Bahaya Pornografi Melalui Media Elektronik Bagi Remaja Berbasis Penyuluhan Hukum-Suci Flambonita, Vera Novianti, Artha Febriansyah

DOI: https://doi.org/10.31004/abdidas.v2i3.324

\section{HASIL DAN PEMBAHASAN}

Objek pornografi terdapat pada benda, tulisan dan gambar yang melekat pada kertas, baik lembar kertas maupun majalah, tabloid dan sebagainya. KUHP Indonesia tidak secara jelas/eksplisit. Hal ini terlihat dari Pasal 1 Undangundang Nomor 44 Tahun 2008 tentang Pornografi menyebutkan "pornografi adalah gambar, sketsa, ilustrasi, foto, tulisan, suara, bunyi, gambar bergerak, animasi, kartun, percakapan, gerak tubuh atau bentuk pesan lainnya melalui berbagai bentuk media komunikasi dan/atau pertunjukkan di muka umum, yang memuat kecabulan dan eksploitasi seksual yang melanggar norma kesusilaan dalam masyarakat".

Dalam penyampaian penyuluhan hukum yang membahas bagaimana bahaya dari pornografi, sebagai bahasan pertama dalam penyampaian tersebut adalah mengenai batasan pornografi dalam Undang-undang Nomor 44 Tahun 2008 (selanjutnya disebut dengang UU Pornografi) menerangkan hal-hal sebagai berikut:

a. Pornografi menurut Undang-undang Pornografi lebih luas dari KUHP. Objeknya menurut KUHP adalah tulisan, gambar dan benda yang diperluas, termasuk alat mencegah dan menggugurkan kehamilan, objek pornografi menurut UU Pornografi telah diperluas sedemikian rupa, sehingga termasuk gambar, sketsa, ilustrasi, foto, tulisan, suara, bunyi, gambar bergerak, animasi, kartun, percakapan, gerak tubuh atau bentuk pesan lainnya melalui media komunikasi. b. Ada tiga (3) sifat yang melekat pada bentukbentuk pornografi yaitu: a) memuat kecabulan atau, b) eksploitasi seksual, dan c) melanggar norma kesusilaan dalam masyarakat.

c. Berdasarkan beberapa ketentuan yang termaktub dalam KUHP, pada Pasal 283 dapat dinyatakan bahwa:

1. Tindakan seksual terhadap anak ditempatkan sebagai kejahatan yang meliputi; tindakan perkosaan, tindakan pemaksaan perbuatan cabul terhadap anak di bawah 15 tahun, baik dengan dirinya ataupun dengan orang lain; pencabulan dengan anak sesama jenis; pencabulan dengan bujukan dan tawaran imbalan berupa uang atau lainnya; pencabulan oleh orang tua atau walinya.

2. Tidak ada pengaturan mengenai orang yang melakukan kegiatan dalam prostitusi. Kejahatan hanya ditujukan kepada orang yang mengambil keuntungan dari perbuatan cabul dan kegiatan sebagai mucikari yang mengambil keuntungan dari prostitusi.

3. Merupakan tindakan kejahatan, tindakan perdagangan perempuan dan anak lakilaki yang belum dewasa.

4. Tidak ada pengaturan mengenai anak yang dijadikan sebagai subyek bahanbahan pornografi baik secara nyata maupun simulasi. Hal yang diatur adalah tindakan menawarkan, menyerahkan, memperlihatkan, mendengarkan isi surat, naskah, gambar atau bahan yang 
608 Bahaya Pornografi Melalui Media Elektronik Bagi Remaja Berbasis Penyuluhan Hukum-Suci Flambonita, Vera Novianti, Artha Febriansyah

DOI: https://doi.org/10.31004/abdidas.v2i3.324

bertentangan dengan norma kesopanan umum kepada seorang anak (di bawah 17 tahun). Eksploitasi seksual Komersial terhadap Anak (ESKA) yang diidentifikasikan ke dalam tiga bentuk, yaitu prostitusi anak, pornografi anak, dan perdagangan anak untuk tujuan seksual, menjadi salah satu perhatian.

Dengan demikian, permasalahan pornografi bukan hanya permasalahan pemerintah, tetapi sudah merupakan masalah masyarakat secara bersama-sama untuk meningkatkan pemahaman masyarakat tentang bahaya pornografi dan harus diselesaikan (Tri Utomo \& Sa'i, 2018).

Batasan usia anak belum secara baku diatur dalam suatu undang-undang, namun yang ada hanya kapan seseorang dikatakan dewasa dan dianggap cakap untuk melakukan hal-hal untuk orang dewasa, diantaranya:

a) Menurut Gunarso D Singgih dan Yulia D. Gunarsa dalam Tolib Setiady menyebutkan "remaja merupakan masa peralihan antara masa anak dan masa dewasa, yakni 12 sampai 21 tahun"(Maisya \& Masitoh, 2020)

b) Undang-undang Nomor: 4 Tahun 1979 tentang Kesejahteraan Anak menyebutkan" usia anak diatur dalam Pasal 1 butir 2 bahwa: anak adalah seseorang yang belum mencapai umur 21 (dua puluh satu) tahun dan belum pernah kawin".

c) UU Nomor: 1 Tahun 1974 tentang Perkawinan yang jo menjadi Undangundang Nomor 15 Tahun 2019.

d) UU No. 1 Tahun 1974 tentang Perkawinan, menentukan bahwa membatasi usia anak di bawah kekuasaan orang tua atau di bawah perwalian sebelum mencapai usia 18 (delapan belas) tahun.

e) UU No. 11 Tahun 2012 tentang Sistem Peradilan Anak.

f) Batas umur anak nakal dapat diajukan ke sidang anak adalah sekurang-kurangnya 8 (delapan) tahun tetapi belum mencapai umur 18 (delapan belas) tahun dan belum pernah kawin.

g) Kitab Undang-Undang Hukum Perdata.

h) Pasal 330 ayat (1) memuat batas antara belum dewasa (minderjarigheid) dengan telah dewasa (meerderjarigheid) yaitu umur 21 (dua puluh satu) tahun kecuali anak itu sudah kawin dan belum umur 21 tahun dan pendewasaan.

i) UU No. 39 Tahun 1999 tentang Hak Asasi Manusia (HAM).

j) Dalam Pasal 1 sub 5 dinyatakan bahwa anak adalah setiap manusia yang berusia di bawah 18 (depan belas) tahun dan belum menikah, termasuk anak yang masih dalam kandungan apabila hal tersebut adalah demi kepentingannya;

k) Resolusi PBB tentang Standars Minimun Rules for the Administration of Juvenile (SMR-JJ) menetapkan batasan anak adalah seseorang yang berusia 7-18 tahun (commentary Rule 2.2) dan Resolusi PBB No. 45/113 menentukan batasan atas yaitu 18 tahun (Rule 119(a)).

1) Convention on the Right of Child (CRC) atau KHA menetapkan anak berarti setiap manusia di bawah umur 18 tahun, kecuali 
609 Bahaya Pornografi Melalui Media Elektronik Bagi Remaja Berbasis Penyuluhan Hukum-Suci Flambonita, Vera Novianti, Artha Febriansyah

DOI: https://doi.org/10.31004/abdidas.v2i3.324

menurut undang-undang yang berlaku pada

anak, kedewasaan dicapai lebih awal

(Haidar \& Apsari, 2020).

Sedangkan di dalam hukum adat tidak ada batasan usia secara signifikan berapa batasan usia anak. Menurut R. Soepomo manusia dikatakan dewasa apabila: a) kuwat gawe diartikan sebagai orang yang sudah dapat memenuhi kebutuhannya secara mandiri, b) cakap, apabila ia telah dapat mengurus harta kekayaan keluarga. Biasa perkembangan anak hingga dewasa dikaitkan dengan usia dan kecendurungan kondisi kejiwaannya terbagi dalam lima tahap sebagai berikut: a) anak, seseorang yang berusia di bawah 12 tahun, b) remaja dini, seseorang yang berusia 12-15 tahun, c) remaja penuh, seseorang yang berusia 15-17 tahun, d) dewasa muda, seseorang yang berusia 17-21 tahun, e) dewasa, seseorang uang berusia di atas 21 tahun (Maisya \& Masitoh, 2020).

Dengan mengadakan tanya jawab antara tim penyuluh dengan peserta, guna mencapai satu pemahaman tentang apa yang menjadi bahaya dari pornografi melalui media elektronik bagi remaja tersebut. Film porno dapat mempengaruhi sikap dan perilaku remaja/siswa, dimana sikap dan perilaku tersebut dapat terjadi apabila terdapat dorongan dalam diri remaja untuk menyaksikan tayangan dan mengimitasi hal-hal yang terdapat dalam film porno. Sebenarnya film merupakan hiburan yang murah dan praktis. Akan tetapi dengan semakin banyaknya film porno, seperti kecendrungan remaja/siswa menonton film porno akan mengakibatkan siswa sulit berkonsetrasi dalam belajar, sehingga hasil belajarnya rendah. (Ali \& E, 2018)

\section{SIMPULAN}

Penyuluhan ini memberikan informasi dan pengetahuan tentang bahaya pornografi melalui media elektronik bagi remaja, disebabkan banyaknya situs porno maupun akses mudah untuk memperoleh gambar porno melalui media elektronik, sangat berbahaya sekali bagi perkembangan jiwa anak khususnya anak-anak usia sekolah, karena pada prinsipnya anak adalah sebagai cikal bakal generasi penerus bangsa. Salah satu contohnya adalah melakukan kenakalan berupa melakukan tindakan asusila sampai kepada melakukan perbuatan seperti pemerkosaan dan sampai pada pembunuhan, yang semuanya merupakan efek bahaya dari tontonan yang mereka lihat melalui media elektronik. Misalnya internet yang sangat mudah mereka akses, karenanya sangat diperlukan pengawasan dari pihak keluarga dan sekolah serta menanamkan pondasi agama yang kuat terhadap anak-anak, khususnya di kalangan remaja.

\section{UCAPAN TERIMA KASIH}

Terima kasih kepada tim pengabdian kepada masyarakat Fakultas Hukum Universitas Sriwijaya dan juga kepada Kepala Sekolah SMA N 2 Pangkal Pinang, Provinsi Kepulauan Bangka Belitung, serta siswa-siswa kelas 10 sampai dengan kelas 12 . 
610 Bahaya Pornografi Melalui Media Elektronik Bagi Remaja Berbasis Penyuluhan Hukum-Suci Flambonita, Vera Novianti, Artha Febriansyah

DOI: https://doi.org/10.31004/abdidas.v2i3.324

\section{DAFTAR PUSTAKA}

Ali, R., \& E, M. H. F. S. (2018). Bimbingan Kepada Orang Tua Untuk Mencegah.

Haidar, G., \& Apsari, N. C. (2020). Pornografi Pada Kalangan Remaja Beserta Dampaknya. Prosiding Penelitian Dan Pengabdian Kepada Masyarakat, 7(1), 136.

Hariyani, M., Mudjiran, M., \& Syukur, Y. (2012). Dampak Pornografi Terhadap Perilaku Siswa dan Upaya Guru Pembimbing untuk Mengatasinya. Konselor, 1(2), 1-8. https://doi.org/10.24036/0201212696-0-00

Maisya, I. B., \& Masitoh, S. (2020). Derajat Keterpaparan Konten Pornografi Pada Siswa Smp Dan Sma Di Dki Jakarta Dan Banten Indonesia. Jurnal Kesehatan Reproduksi, $10(2)$, $117-126$. https://doi.org/10.22435/kespro.v10i2.2463

Marchira, C. R. (2019). Dampak Pornografi Terhadap Kesehatan Jiwa. Dept Psikiatri FKKMK Universitas Gadjah Mada. http://obgin-ugm.com/wpcontent/uploads/2019/04/Dampak-

Pornografi-Jiwa-Carla.pdf

Rina, E. V., \& Tianingrum, N. A. (2019). Pengaruh Lingkungan Terhadap Perilaku Kenakalan Remaja Sekolah Di Wilayah Kerja Puskesmas Harapan Baru Kota Samarinda. Borneo Student Research, 1(1), 345-352.

Suyatno, T. (2011). Pengaruh Pornografi Terhadap Perilaku Belajar Siswa ( Studi Kasus: Sekolah Menengah X ). Jurnal Pendidikan Dompet Dhuafa, 1-12.

Tri Utomo, S., \& Sa'i, A. (2018). Perkembangan Mental Remajadi Sekolah. Elementary Vol.6/No.1/Januari-Juni2018, 6(1), 167-187.

Peraturan Perundang-undangan

Republik Indonesia, Undang-undang Nomor 11 Tahun 2012 tentang Sistem Peradilan Anak

Republik Indonesia, Undang-undang Nomor 1 Tahun 1974 jo Undang-undang Nomor 15 Tahun 2019 Tentang Perkawinan

Republik Indonesia, Undang-undang Nomor 39 Tahun 1999 Tentang Hak Asasi Manusia. 